\title{
Article \\ Deterioration of Property of Aluminum Alloys (EN AW-1050A, EN AW-5754 and EN AW-6060) by Absorbed Hydrogen
}

\author{
Paweł P. Włodarczyk *(D) and Barbara Włodarczyk *(D) \\ Institute of Environmental Engineering and Biotechnology, Faculty of Natural Sciences and Technology, \\ University of Opole, ul. Kominka 6a, 45-032 Opole, Poland \\ * Correspondence: pawel.wlodarczyk@uni.opole.pl (P.P.W.); barbara.wlodarczyk@uni.opole.pl (B.W.); \\ Tel.: +48-77-401-60-48 (P.P.W.)
}

Featured Application: The selection of aluminum alloys (as construction materials) exposed to hydrogen, e.g., hydrogen supply pipes, fuel cell parts, block of combustion engine powered by hydrogen, etc.

\begin{abstract}
The paper reports the results of research on the effect of hydrogen penetration on the variations in the mechanical properties of selected aluminum alloys. As a result of the study, it can be observed that such variations contribute to the deterioration of mechanical properties, which, in turn, contributes to shortening the reliability time associated with the operation of aluminum alloy structures. The analysis involved structural aluminum alloys: EN AW-1050A, EN AW-5754 and EN AW-6060. Tensile strength and impact strength were measured. It was demonstrated that the absorption of hydrogen by the analyzed alloys led to the deterioration of mechanical properties of aluminum alloys. The performed measurements were compared to the previous research results regarding the influence of hydrogen on the deterioration of corrosion properties. The analysis of the influence of hydrogen on both issues allowed us to notice the reasons for shortening the operational reliability time of aluminum alloy parts. The awareness of the influence of hydrogen on aluminum alloys may contribute to the development of hydrogen systems or installations in which aluminum alloys can be used as a construction material, e.g., fuel cells, hydrogen supply pipes, block of combustion engine powered by hydrogen, etc. In the era of the development of zero-emission vehicles, the use of hydrogen as fuel is gaining more and more importance, where the influence of hydrogen on the properties of materials is an important issue.
\end{abstract}

Keywords: aluminum alloys; hydrogenation; tensile strength measurements; impact strength measurements; environmental engineering; reliability

\section{Introduction}

In the era of development of environmentally friendly energy or automotive industry, in which the increase of the share of hydrogen as fuel is planned, it is important to recognize the influence of this gas on the properties of construction materials such as aluminum alloys. The influence of hydrogen on metals was observed more than half a century ago (1960s) [1]. Hydrogen absorption in metals causes their "hydrogen embrittlement" [2-4], as well as changes in their electrochemical properties [5-7]. Hydrogen embrittlement causes a reduction in mechanical properties, while a change in electrochemical properties causes a reduction in the corrosive properties of metal alloys [5]. Lowering both types of properties result in shortening the operational reliability time [8,9], which may affect both the safety of users and the shorter service life of metal alloy constructions [10-12]. The knowledge of the influence of hydrogen on structural alloys may allow us to increase the safety of use, but also to extend the service life of devices, which in turn contributes to environmental protection, as it postpones the need to manufacture new parts [13]. For this reason, research

Copyright: (C) 2022 by the authors Licensee MDPI, Basel, Switzerland. This article is an open access article distributed under the terms and conditions of the Creative Commons Attribution (CC BY) license (https:// creativecommons.org/licenses/by/ $4.0 /)$. on the influence of hydrogen on various types of metal alloys is very important. 
The most widely used construction materials are still metal alloys [14-17]. Due to the appropriate mechanical parameters and relatively low-price, steels are mainly used $[18,19]$. However, aluminum alloys, which are increasingly used in the aviation, space industry, automotive [19-21], shipbuilding and many other industries [22,23], including space industries [24], also occupy a permanent place. Aluminum alloys are used not only as a material for the body structure of a vehicle, but also as a material for suspensions, inlet manifolds, gearbox housings, engine blocks, cylinders heads, but also pneumatic and liquid lines [25]. Some aluminum structural elements may be exposed to hydrogen ingress [26-28]. Such a situation occurs in the case of aluminum hydrogen pipes, aluminum hydrogen powered combustion engines or fuel cells (where the structural parts are made of aluminum alloys) $[29,30]$. In fact, in most of these cases, the hydrogenation of aluminum alloys occurs in contact with gaseous hydrogen (often under pressure). However, in the first place, the authors wanted to continue research on the influence of hydrogen on the previously studied types of alloys. Earlier studies included measurements of the effect of hydrogen on corrosive properties of aluminum alloys [7] during electrolytic hydrogenation, and therefore the next step is to perform measurements on the mechanical strength of the same type of alloys during the same type of hydrogenation.

Generally, aluminum alloys are corrosion resistant materials. However, the highly corrosion-resistant aluminum alloys do not have high resistance to the stress corrosion crack (SCC) propagation and may deteriorate under operating conditions due to fracture and corrosion fatigue [31]. Hydrogen is stored in the spaces inside the metal in molecular form $\left(\mathrm{H}_{2}\right)$, which increases the pressure of hydrogen in the volume of the metal. This pressure causes internal stresses and blisters, which significantly reduces the mechanical resistance of the metal [32]. Moreover, the real metal crystal lattice is characterized by many crystallographic defects [33]. Due to the defects of the crystal lattice and the uneven stress distribution, the absorbed hydrogen is also unevenly distributed [32,33].

Unevenly absorbed hydrogen causes distortions of the crystal lattice, which in turn affects the formation of local internal stresses. Such uneven distribution of the absorbed hydrogen also causes uneven distribution where tensile stresses occur, which consequently lowers the mechanical properties of metal alloys. Thus, such a situation also adversely affects the properties of structures made of aluminum alloys. The concentration of hydrogen increases at the points of the highest tensile stresses [1,2,33], e.g., at the tip of corrosion cracks [13]. It should be noted that the stepwise deepening of the fissure occurs from the point of the highest mechanical stresses to the tip of the crack.

One of the main indicators characterizing the stress corrosion process in metals (or metal alloys) is the stress intensity factor $K_{1}$, which is a parameter that determines the mechanical state of stresses in the volume at the crack tip [34-37]. While the critical value of the stress intensity factor $K_{1 C}$ determines the moment above which the separation crack of the material occurs [30,35,37].

The stress cracking process occurs mainly in three stages [34,35]:

Stage I-nucleation and growth of a SCC. The crack propagation rate increases rapidly. The beginning of the SCC nucleation occurs at a point $K_{1 C C}$.

Stage II - a sharp decrease in the crack propagation rate. The crack propagates at a constant rate (crack branching occurs).

Stage III-rapid acceleration of the crack propagation rate. The crack depth increases over the entire width of the specimen (material separation).

Thus, each reduction of the stress intensity factor of the $K_{1}$ value (caused by the absorbed hydrogen at any stage of crack) will reduce the mechanical properties of the alloy and accelerate the destruction of the material, which in turn, will shorten the operational reliability time of the aluminum alloys' structures.

This paper is the continuation of the previous research on the effects of hydrogen on aluminum alloys $[7,30]$. Previous studies have shown that the absorption of hydrogen by aluminum alloys contributes to changes in electrochemical properties, which leads to the formation of electrochemical galvanic cells (which reduce corrosion resistance of 
aluminum alloys) [30]. When continuing the research on the influence of hydrogen on the selected aluminum alloys [7,30], it seems important to conduct research on the influence of hydrogen on the change of the mechanical properties of the same alloys. Preliminary measurements have shown that hydrogen changes the mechanical properties of aluminum alloys to some extent [30].

The work covers research on the influence of hydrogen on the mechanical properties of aluminum alloys (EN AW-1050A, EN AW-5754, EN AW-6060).

\section{Materials and Methods}

The research material were the samples of technical aluminum alloys for forming processes: EN AW-1050A, EN AW-5754 and EN AW-6060. Selected alloys are readily available and widely used as a construction material. All analyzed alloys are also easily weldable [38]. The chemical composition of the alloys is summarized in Table 1.

Table 1. Chemical composition (standard limit of the composition) of aluminum alloys applied in measurements-percentage of alloying elements [38].

\begin{tabular}{ccccccccccc}
\hline Alloy Designation & Si & Fe & Cu & Mn & Mg & Cr & Zn & Ti & Others & $\begin{array}{c}\text { Initial } \\
\text { State }\end{array}$ \\
\hline EN AW-1050A & 0.25 & 0.40 & 0.05 & 0.05 & 0.05 & - & 0.07 & 0.05 & - & “O” \\
EN AW-5754 & 0.40 & 0.40 & 0.10 & 0.50 & $2.60-3.60$ & 0.30 & 0.20 & 0.15 & 0.15 & “O” \\
EN AW-6060 & $0.30-0.60$ & $0.10-0.30$ & 0.10 & 0.10 & $0.30-0.60$ & 0.05 & 0.15 & 0.10 & 0.15 & “O” \\
\hline
\end{tabular}

The tests were carried out in two areas: tensile strength measurements (universal testing machine) and impact strength measurements (Charpy hammer). In both cases, measurements were performed without hydrogenation and after electrolytic hydrogenation of the specimens.

The hydrogenation of the specimens was carried out in a Hoffman apparatus in a $0.1 \mathrm{~N} \mathrm{H}_{2} \mathrm{SO}_{4}$ solution. The anode was made of platinum (No. 3 in Figure 1), whereas the aluminum alloy specimens (No. 4 in Figure 1) formed the cathode in the process. The specimens were hydrogenated for 10 and $25 \mathrm{~min}$. Cathodic polarization was carried out at a current of $20 \mathrm{~mA}$. The hydrogenation in a Hoffman apparatus was shown in Figure 1.

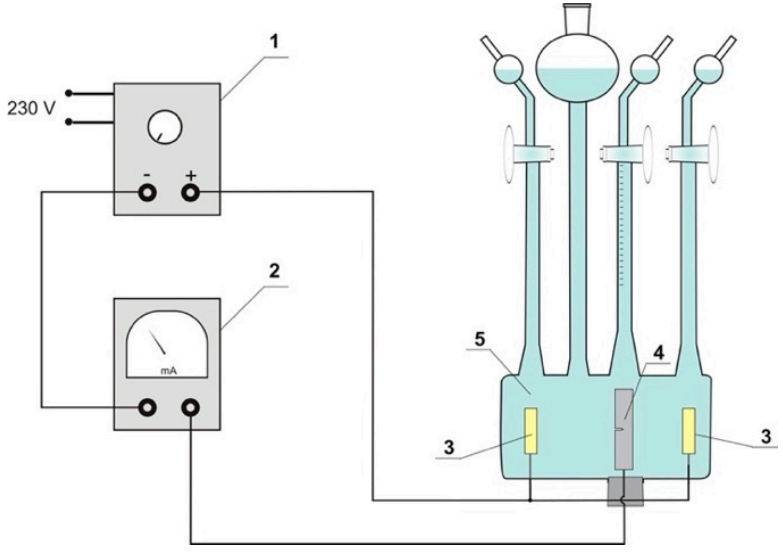

Figure 1. The hydrogenation in a Hoffman apparatus. 1-power supply, 2-amperemeter, 3auxiliary electrode (platinum electrode), 4-analyzed aluminum alloy (cathode), and 5-electrolyte (0.1 $\mathrm{N} \mathrm{H}_{2} \mathrm{SO}_{4}$ solution).

Tensile strength measurements were carried out according to PN-EN ISO 6892-1:202005 [39] at $20^{\circ} \mathrm{C}$. The test specimens were prepared as pre-cracked specimens. Pre-cracks provide better reproducibility of results compared to smooth specimens [40]. Moreover, when the location of the crack is predetermined, it is easier to measure parameters such as, e.g., crack propagation rate [41]. The specimens were prepared in accordance with 
PN-EN ISO 6892-1:2020-05 [39]. The dimensions of the specimens were, respectively: width $10 \mathrm{~mm}$, thickness $5 \mathrm{~mm}$. The geometry of notch: width $1 \mathrm{~mm}$, depth $4.5 \mathrm{~mm}$. During the measurement, the specimens were kept in a $3 \%$ solution of chemically pure $\mathrm{NaCl}$ to ensure measurement in corrosive conditions (Figure 2). The measuring vessel used was a glass vessel, indifferent to the corrosive environment $(3 \%$ aqueous solution of $\mathrm{NaCl})$. At the point where the specimen passed through the vessel wall a gasket (No. 4 in Figure 2) made of a rubber-like material (FiberFlex) was used. The gasket ensured the vessel tightness during the measurement. The gasket was produced with the use of 3D printing technology. During the tear-off measurements, not only the force applied to the specimens was measured, but also its electrical resistance. For this purpose, electrodes were placed at the ends of the specimen, allowing the flow and measurement of electric current through the specimen (No. 5 in Figure 2).

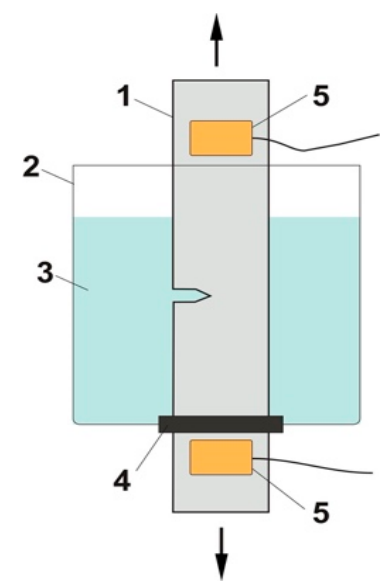

Figure 2. Scheme of holding the specimen during the measurement in corrosive conditions. 1specimen, 2-glass vessel, 3-electrolyte, 4-gasket, and 5-electrodes.

The flow of electricity made it possible to measure the resistance of the specimen. The resistance increases with the reduction of the cross-section of the specimen, and at the time of its rupture it reached its maximum value (solution resistance). The collected data of force (needed to burst the specimen) and resistance made it possible to plot the relationship between the cracking rate and the value of the stress intensity factor $K_{1}$. Measurements were carried out for alloys without hydrogenation and for electrolytically hydrogenated alloys.

A notch was cut $2 \mathrm{~mm}$ deep in the center of one of the side walls in a direction perpendicular to the longitudinal axis of the specimen. This incision was made to create a stress concentration causing the break of specimen. Without a notch, the specimen would only bend [41]. The specimen lay perpendicularly on the supports and was adhered to the supports in such a way that the symmetry plane of the notch from the symmetry plane of the supports did not exceed $0.5 \mathrm{~mm}$. The aluminum alloy specimens used in measurements was shown in Figure 3.

In case of all grades of aluminum alloys and for both types of measurements, each measurement was repeated 15 times. The mean square error to calculate the measurement errors was used. The research scheme is shown in Figure 4.

Impact strength measurements (No. 6 in Figure 4) were carried out with a Charpy hammer according to PN-EN ISO 148-2:2017-02 [42] at a temperature of $20^{\circ} \mathrm{C}$. During the impact tests, specimens with a U-notch $(2 \mathrm{~mm})$ were used. The size of the specimens according to PN-EN ISO 148-2:2017-02 [42] was $55 \mathrm{~mm} \times 10 \mathrm{~mm} \times 10 \mathrm{~mm}$. The specimens were "cold" cut with metal cutting machine tools [42,43]. Chip machine was applied to the material to avoid local overheating, e.g., during local heating with a burner, which could change the properties of the specimens [44-46]. After making the specimens had annealed them in furnace within $1 \mathrm{~h}$ at a temperature of $350^{\circ} \mathrm{C}$. 

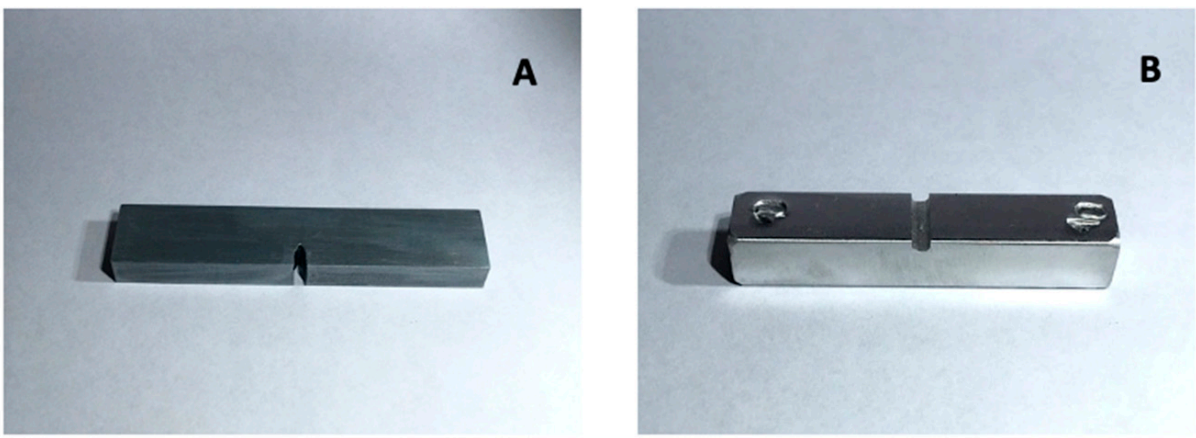

Figure 3. Aluminum alloy specimens: (A)—specimen for the tensile strength measurements, and (B)-specimen for the impact strength measurements.

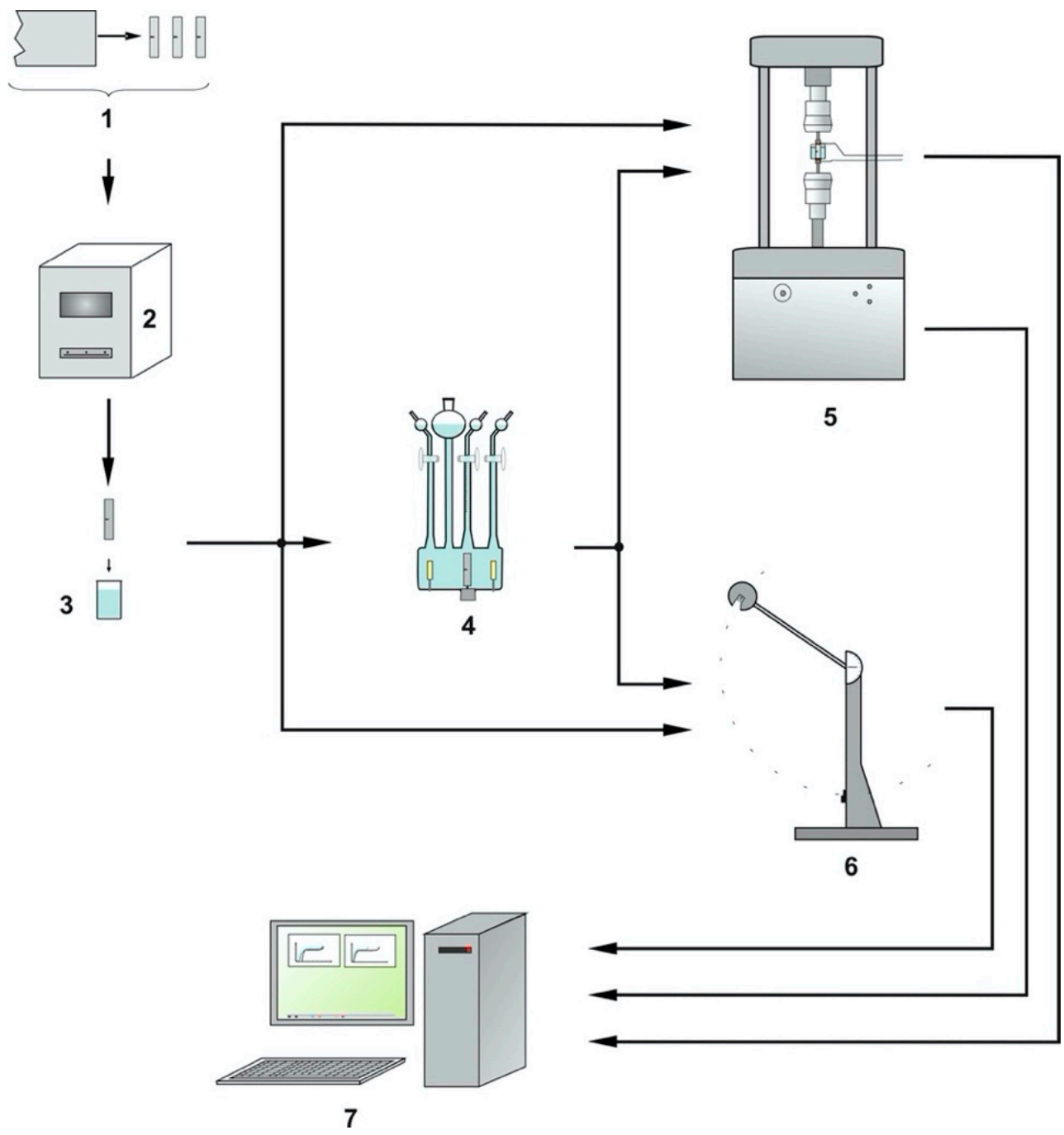

Figure 4. Preparation and experimental setups and schedule of measurements. 1-preparation of alloy specimens, 2-annealing in a muffle furnace, 3-degreasing alloy specimens, 4-Hoffman apparatus, 5-universal testing machine, 6-Charpy hammer, and 7-computer.

The Hoffman apparatus (Fabryka Pomocy Naukowych, Nysa, Poland) was used for hydrogenation of specimens. The UMM-5 universal materials testing machine (ASMAPribor, Svitlovodsk, Ukraine) was used for the measurements of the influence of the stress intensity factor on the speed of crack propagation. The 402 impact testing machine (VEB Werkstoffprüfmaschinen, Leipzig, East Germany) was used for the impact measurements. 
The KS 520/14 silt furnace (ELIOG Industrieofenbau GmbH, Römhild, Germany) was used for annealing of alloy specimens. A Zortrax M200 printer (Zortrax S.A, Olsztyn, Poland) was used to print a rubber gasket of glass vessel for measurement in corrosive environment. To prepare the 3D object (rubber gasket) for printing, Z-Suite software (Zortrax S.A, Olsztyn, Poland) was used.

\section{Results}

\subsection{Tensile Strength Measurements}

Figures 5-7 show the tensile tests of the analyzed alloys: non-hydrogenated and hydrogenated-for 10 and 25 min of hydrogenation.

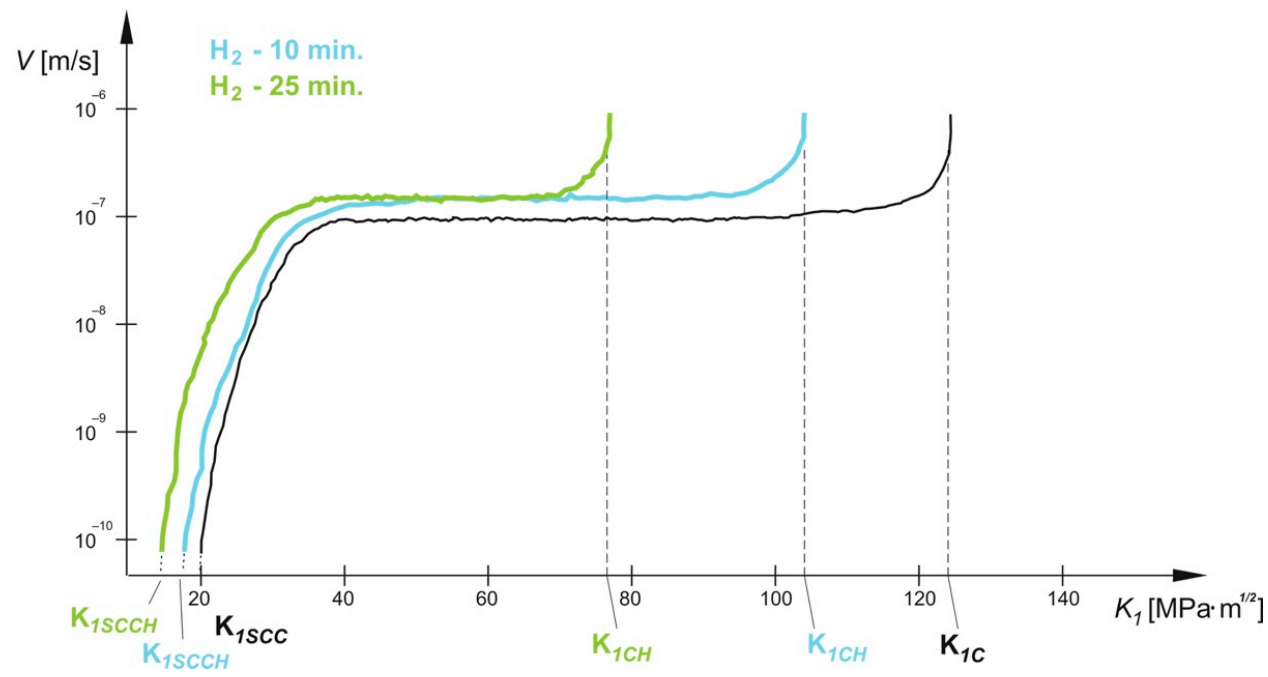

Figure 5. The dependence of the crack propagation rate on the value of the stress intensity factor $K_{1}$ for not-hydrogenated and hydrogenated $\left(\mathrm{H}_{2}\right)$ 1050A alloy-time of the hydrogenation: 10 and $25 \mathrm{~min}$. $\mathrm{K}_{1 \mathrm{SCC}}$-nucleation and growth of a stress corrosion crack; $\mathrm{K}_{1 \mathrm{SCCH}}$-nucleation and growth of a stress corrosion crack after hydrogenation; $\mathrm{K}_{1 \mathrm{C}}-$ material separation; and $\mathrm{K}_{1 \mathrm{CH}}$-material separation after hydrogenation.

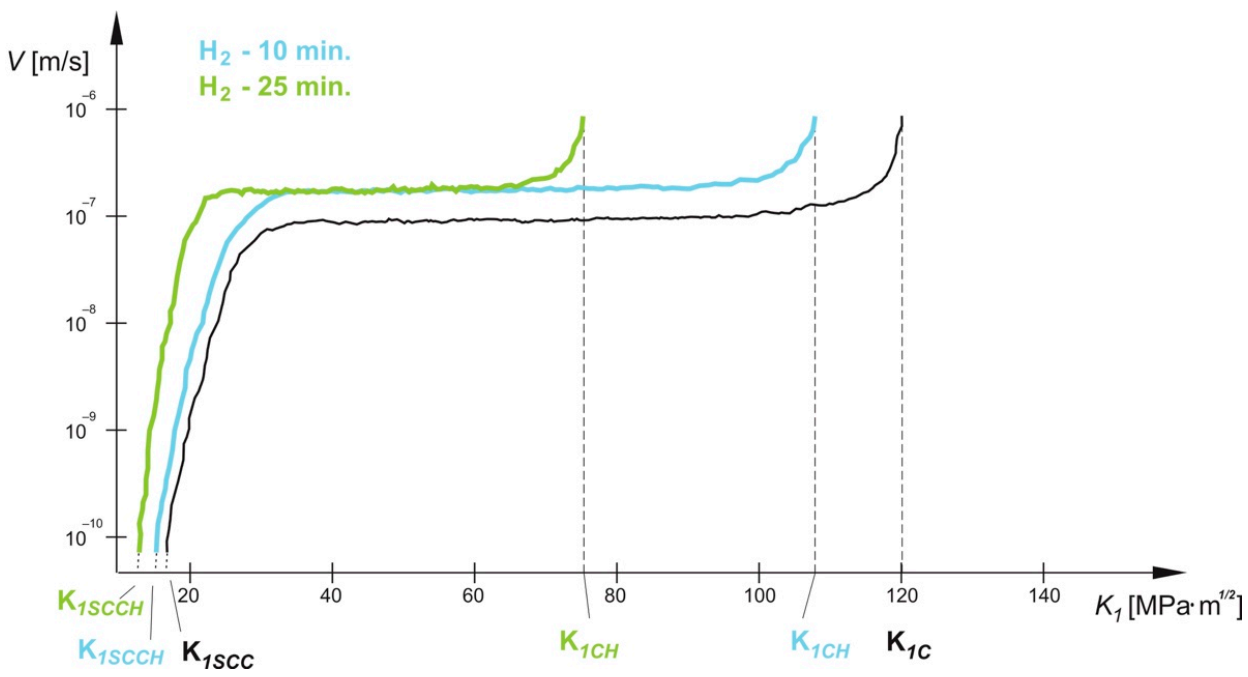

Figure 6. The dependence of the crack propagation rate on the value of the stress intensity factor $K_{1}$ for not-hydrogenated and hydrogenated $\left(\mathrm{H}_{2}\right) 5754$ alloy-time of the hydrogenation: 10 and 25 min. $K_{1 S C C}$-nucleation and growth of a stress corrosion crack; $K_{1 S C C H}$-nucleation and growth of a stress corrosion crack after hydrogenation; $\mathrm{K}_{1 \mathrm{C}}$-material separation; and $\mathrm{K}_{1 \mathrm{CH}}$-material separation after hydrogenation. 


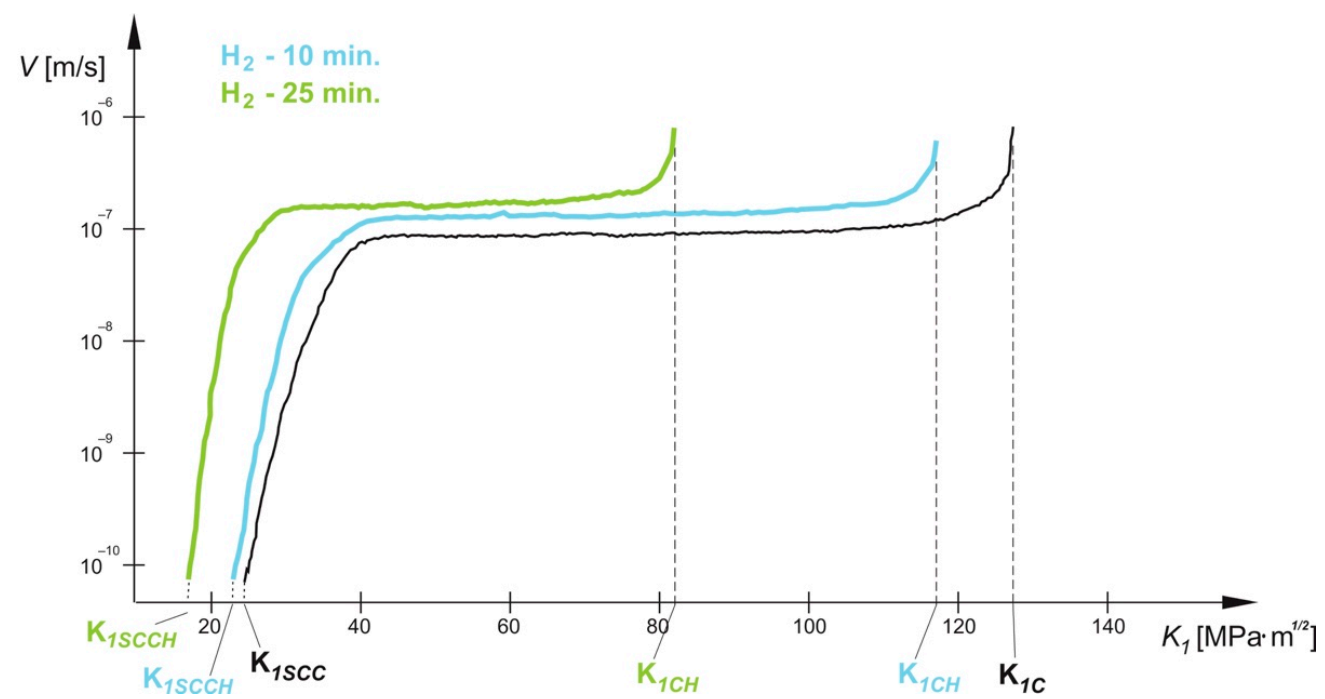

Figure 7. The dependence of the crack propagation rate on the value of the stress intensity factor $K_{1}$ for not-hydrogenated and hydrogenated $\left(\mathrm{H}_{2}\right) 6060$ alloy—time of the hydrogenation: 10 and $25 \mathrm{~min}$. $\mathrm{K}_{1 \mathrm{SCC}}$-nucleation and growth of a stress corrosion crack; $\mathrm{K}_{1 \mathrm{SCCH}}$-nucleation and growth of a stress corrosion crack after hydrogenation; $\mathrm{K}_{1 \mathrm{C}}$-material separation; and $\mathrm{K}_{1 \mathrm{CH}}$-material separation after thydrogenation.

\subsection{Impact Strength Measurements}

The results of the performed impact tests are presented in Table 2.

Table 2. Experimental data on impact strength measurements, before and after hydrogenation.

\begin{tabular}{|c|c|c|c|c|}
\hline \multicolumn{2}{|c|}{ Aluminum Alloy Designation } & \multirow{2}{*}{$\begin{array}{c}\text { Impact Strength } \\
{\left[\mathrm{J} \cdot \mathrm{cm}^{-2}\right]}\end{array}$} & \multirow{2}{*}{$\begin{array}{c}\text { Impact Strength } \\
\text { after } \\
\text { Hydrogenation } \\
\left(\mathrm{H}_{2}-10 \mathrm{~min}\right) \\
{\left[\mathrm{J} \cdot \mathrm{cm}^{-2}\right]}\end{array}$} & \multirow{2}{*}{$\begin{array}{c}\text { Impact Strength } \\
\text { after } \\
\text { Hydrogenation } \\
\left(\mathrm{H}_{2}-25 \mathrm{~min}\right) \\
{\left[\mathrm{J} \cdot \mathrm{cm}^{-2}\right]}\end{array}$} \\
\hline by Number & $\begin{array}{l}\text { by Chemical } \\
\text { Symbols }\end{array}$ & & & \\
\hline EN AW-1050A & EN AW-Al. 99.5 & $104 \pm 4$ & $93 \pm 5$ & $65 \pm 2$ \\
\hline EN AW-5754 & EN AW-Al. Mg3 & $42 \pm 2$ & $40 \pm 3$ & $31 \pm 3$ \\
\hline EN AW-6060 & EN AW-Al MgSi & $53 \pm 3$ & $49 \pm 3$ & $37 \pm 2$ \\
\hline
\end{tabular}

\section{Discussion}

In the case of the tensile strength measurements, all the obtained curves for hydrogenated alloys, as well as for unhydrogenated alloys, follows a three-stage scheme. The characteristics of the curves for hydrogenated alloys are similar to the one obtained for unhydrogenated alloys.

Based on the obtained results, it was found that for each of the analyzed alloys, hydrogenation of the specimens increases the cracking rate, and thus weakens their mechanical resistance.

The mean square error did not exceed $3 \%$ of the value in the entire measurements range.

For the alloy 1050A (Figure 5), the nucleation of the crack propagation after hydrogenation $\left(\mathrm{K}_{1 \mathrm{SCCH}}\right)$ of the specimen is lower by approx. 5\% (for $10 \mathrm{~min}$ of hydrogenation) and $20 \%$ (for $25 \mathrm{~min}$ of hydrogenation) than the $K_{1 S C C}$ value without hydrogenation. The critical value at which the specimen breaks is, in the case of a hydrogenated alloy $\left(\mathrm{K}_{1 \mathrm{CH}}\right)$, lower by approx. 16\% (for 10 min of hydrogenation) and by approx. $45 \%$ (for 25 min of hydrogenation) than the $K_{1 C}$ value of the non-hydrogenated alloy.

For the alloy 5754 (Figure 6), the nucleation of the crack propagation after hydrogenation $\left(\mathrm{K}_{1 \mathrm{SCCH}}\right)$ of the specimen is lower by approx. $3 \%$ (for $10 \mathrm{~min}$ of hydrogenation) 
and $15 \%$ (for 25 min of hydrogenation) than the $K_{1 S C C}$ value without hydrogenation. The critical value at which the specimen breaks is, in the case of a hydrogenated alloy $\left(\mathrm{K}_{1 \mathrm{CH}}\right)$, lower by approx. 12\% (for $10 \mathrm{~min}$ of hydrogenation) and by approx. $40 \%$ (for 25 min of hydrogenation) than the $K_{1 C}$ value of the non-hydrogenated alloy.

For the alloy 6060 (Figure 7), the nucleation of the crack propagation after hydrogenation $\left(\mathrm{K}_{1 \mathrm{SCCH}}\right)$ of the specimen is lower by approx. $4 \%$ (for $10 \mathrm{~min}$ of hydrogenation) and $25 \%$ (for $25 \mathrm{~min}$ of hydrogenation) than the $K_{1 S C C}$ value without hydrogenation. The critical value at which the specimen breaks is, in the case of a hydrogenated alloy $\left(\mathrm{K}_{1 \mathrm{CH}}\right)$, lower by approx. 9\% (for $10 \mathrm{~min}$ of hydrogenation) and by approx. $40 \%$ (for 25 min of hydrogenation) than the $K_{1 C}$ value of the non-hydrogenated alloy.

It should be noted that fracture rate in full range for all the alloys considered is greater for the hydrogenated alloy measurements. The fracture strength value is in all considered cases lower after the hydrogenation of the aluminum alloys. In all cases, the value of the threshold stress intensity factor (the value of the stress intensity factor above which the crack propagation nucleation occurs) reaches a lower value after hydrogenation.

In the case of the impact strength measurements, all specimens (non-hydrogenated and hydrogenated) were characterized by slip scrap (ductile material). The measurement data clearly show that hydrogenation causes the formation of the "hydrogen embrittlement". In each analyzed case after hydrogenation, the force necessary to break the specimen was lower than in case of non-hydrogenated alloys.

The alloy 1050A (Al 99.5) showed the greatest difference in measurements (11\%-for $10 \mathrm{~min}$ of hydrogenation time, and $37 \%$ - for $25 \mathrm{~min}$ of hydrogenation time) before and after hydrogenation. This state is due to the fact that alloy 1050A (Al 99.5) is the alloy containing the lowest amount of elements [38], and therefore has high plasticity. Therefore, the absorbing hydrogen has a significant effect on the hydrogen embrittlement formation in the $1050 \mathrm{~A}$ alloy $[47,48]$. The lowest difference $(5 \%$ - for $10 \mathrm{~min}$ of hydrogenation time, and $26 \%$ - for $25 \mathrm{~min}$ of hydrogenation time) in the results between the non-hydrogenated and the hydrogenated alloys can be seen in the case of alloy 5754 (Mg3). However, this alloy is characterized by the lowest plasticity of all the analyzed alloys. While the difference in measurements, before and after hydrogenation, for alloy 6060 (MgSi) was 8\%_for $10 \mathrm{~min}$ of hydrogenation time, and 30\% - for 25 min of hydrogenation time.

Based on the results of measurements, it can be clearly stated that the hydrogenation of the analyzed alloys causes a reduction in their mechanical properties. Therefore, one of the basic goals should be not only to study the mechanism of the development of stress corrosion cracks in aluminum alloys, but also to find effective methods of inhibiting the development of cracks, and thus extending the operational reliability time of the aluminum structure. There are three effective methods of inhibiting the development of corrosion and stress corrosion cracking: application of protective layers, cathodic protection, and application of corrosion inhibitors. However, the protective coatings are subject to aging, and in the place of their local destruction, points of stress corrosion development are formed, from which the crack propagation begins [9]. While the cathodic protection by the cathodic polarization of metal causes its hydrogenation, it may accelerate the development of stress corrosion cracking. Therefore, it seems that the most effective method of inhibiting the development of stress corrosion cracking is the use of hydrogenation inhibitors. Heavy metal compounds are the most frequently used inhibitors. The advantage of the inhibitor method is its high efficiency. Moreover, the inhibitors can be used with other corrosion protection methods.

In conclusion, along with the study of the mechanism of the development of stress corrosion cracks, one should therefore focus on conducting research aimed at selecting appropriate inhibitors for aluminum alloys. 


\section{Conclusions}

It has been shown that the fracture rate for all the considered alloys (EN AW-6060, EN AW-1050A and EN AW-5754) is higher for the measurements of the alloy subjected to hydrogenation. The value of fracture toughness is lower in all considered cases after the hydrogenation of alloys. In all cases, the value of the threshold stress intensity factor (the value of the stress intensity factor above which the crack propagation nucleation takes place) reaches a lower value after hydrogenation.

In fact, in real conditions (operating conditions) the alloy hydrogenation will be on the lower level. However, apart from the level of hydrogenation, the effect of hydrogen on the considered alloys (EN AW-1050A, EN AW-5754 and EN AW-6060) is undeniable.

In the study the deterioration of the mechanical properties of EN AW-1050A, EN AW-5754 and EN AW-6060 aluminum alloys after hydrogenation was shown. Additionally, analyzing the results from this study and previous results of electrochemical measurements [7], it should be clearly stated that the hydrogenation of EN AW-1050A, EN AW-5754 and EN AW-6060 alloys causes not only deterioration of their mechanical properties, but also a reduction in corrosion resistance.

It was found that the aluminum alloy (EN AW-1050A) with the lowest amount of alloying elements was the least exposed to the effect of hydrogenation. In this case (lowest amount of alloying elements), the mechanical properties of the aluminum alloy changed the least. It was therefore found that increasing the amount of alloying elements lowers the mechanical properties of aluminum alloys after hydrogenation.

The conducted research shows the way of selecting the aluminum alloy to extending the operational reliability time of aluminum structures exposed to hydrogenation. In the era of the development of zero-emission vehicles, the use of hydrogen as fuel is gaining more and more importance, where the influence of hydrogen on the properties of materials is an important issue. Therefore, when designing of the hydrogen installations from the analyzed alloys, the influence of hydrogen on the deterioration of the parameters of aluminum alloys should be considered. Moreover, on the basis of research from this work and previous work [7], due to the better reference to real conditions, future research will be conducted with the same aluminum alloys, but with gaseous hydrogenation.

Author Contributions: Data curation, P.P.W. and B.W.; investigation, P.P.W. and B.W.; methodology, P.P.W.; writing—original draft, P.P.W. and B.W.; writing-review and editing, P.P.W. and B.W.; supervision, P.P.W. All authors have read and agreed to the published version of the manuscript.

Funding: This research received no external funding.

Institutional Review Board Statement: Not applicable.

Informed Consent Statement: Not applicable.

Data Availability Statement: Not applicable.

Conflicts of Interest: The author declares no conflict of interest.

\section{References}

1. Śmiałowski, M. Wodór w Stali; Wydawnictwa Naukowo-Techniczne: Warsaw, Poland, 1961.

2. Śmiałowski, M. Hydrogen in Steel; Pergamon Press: Oxford, UK, 1962.

3. Timmins, P.F. Solutions to Hydrogen Attack in Steels; ASM International: Materials Park, OH, USA, 1997.

4. Flis, J. (Ed.) Wodorowe i Korozyjne Niszczenie Metali; Państwowe Wydawnictwo Naukowe: Warsaw, Poland, 1979.

5. Bala, H. Korozja Materiałów - Teoria i Praktyka; Wydawnictwo Wydziału Inżynierii Procesowej, Materiałowej i Fizyki Stosowanej Politechniki Częstochowskiej: Częstochowa, Poland, 2002.

6. Bala, H. Wstęp do Chemii Materiałów; WNT Wydawnictwa Naukowo-Techniczne: Warsaw, Poland, 2003.

7. Włodarczyk, P.P.; Włodarczyk, B. Effect of hydrogen and absence of passive layer on corrosive properties of aluminum alloys. Materials 2020, 13, 1580. [CrossRef] [PubMed]

8. Laureys, A.; Van den Eeckhout, E.; Petrov, R.; Verbekena, K. Effect of deformation and charging conditions on crack and blister formation during electrochemical hydrogen charging. Acta Mater. 2017, 127, 192-202. [CrossRef] 
9. Oriani, R.A.; Hirth, J.P.; Śmiałowski, M. (Eds.) Hydrogen Degradation of Ferrous Alloys; William Andrew Publishing/Noyes: Norwich, NY, USA, 1989.

10. Dmytrakh, I.M.; Leshchak, R.L.; Syrotyuk, A.M. Effect of hydrogen concentration on strain behaviour of pipeline steel. Int. J. Hydrog. Energy 2015, 40, 4011-4018. [CrossRef]

11. Zhao, Y.; Seok, M.-Y.; Choi, I.-C.; Lee, Y.-H.; Park, S.-J.; Ramamurty, U.; Suh, J.-Y.; Jang, J. The role of hydrogen in hardening/softening steel: Influence of the charging process. Scr. Mater. 2015, 107, 46-49. [CrossRef]

12. Hong, Y.; Zhou, C.; Zheng, Y.; Zhang, L.; Zheng, J.; Chen, X. Effect of hydrogen and strain rate on nanoindentation creep of austenitic stainless steel. Int. J. Hydrog. Energy 2019, 44, 1253-1262. [CrossRef]

13. Atrens, A.; Liu, Q.; Tapia-Bastidas, C.; Gray, E.; Irwanto, B.; Venezuela, J.; Liu, Q. Influence of hydrogen on steel components for clean energy. Corros. Mater. Degrad. 2020, 1, 3-26. [CrossRef]

14. Cather, B.; Doran, D. Construction Materials Reference Book; Butterworth-Heinemann: Oxford, UK, 2012.

15. Horvath, A. Construction materials and the environment. Annu. Rev. Environ. Resour. 2004, 29, 181-204. [CrossRef]

16. Allen, E.; Iano, J. Fundamentals of Building Construction: Materials and Methods; Wiley: Hoboken, NJ, USA, 2019.

17. Domone, P.; Illston, J. Construction Materials: Their Nature and Behaviour; CRC Press: Boca Raton, FL, USA, 2010.

18. Blicharski, M. Wstẹp do Inżynierii Materiałowej; Wydawnictwa Naukowo-Techniczne: Warsaw, Poland, 2003.

19. Jaśkiewicz, Z. (Ed.) Poradnik Inżyniera Samochodowego Elementy i Materiały; Wydawnictwa Komunikacji i Łaczności: Warsaw, Poland, 1990.

20. Blatnický, M.; Sága, M.; Dižo, J.; Bruna, M. Application of Light Metal Alloy EN AW 6063 to Vehicle Frame Construction with an Innovated Steering Mechanism. Materials 2020, 13, 817. [CrossRef]

21. De Almeida, I.; da Silva, L.; Hallak, S. Aluminum Alloy for Automotive Cable-A perspective on emerging cars applications. In SAE Technical Paper; 2010-36-0177; SAE International: Warrendale, PA, USA, 2010. [CrossRef]

22. Kaufman, J.G.; Rooy, E.L. Aluminum Alloy Castings: Properties, Processes, and Applications; ASM International: Novelty, OH, USA, 2004.

23. Barlat, F.; Maeda, Y.; Chung, K.; Yanagawa, M.; Brem, J.C.; Hayashida, Y.; Lege, D.J.; Matsui, K.; Murtha, S.J.; Hattori, S.; et al. Yield function development for aluminum alloy sheets. J. Mech. Phys. Solids 1997, 45, 1727-1763. [CrossRef]

24. Nakai, M.; Eto, T. New aspect of development of high strength aluminum alloys for aerospace applications. Mater. Sci. Eng. A 2000, 285, 62-68. [CrossRef]

25. Papenberg, N.P.; Gneiger, S.; Weißensteiner, I.; Uggowitzer, P.J.; Pogatscher, S. Mg-Alloys for Forging Applications-A Review. Materials 2020, 13, 985. [CrossRef] [PubMed]

26. Łunarska, E.; Chernyayeva, O. Strain induced up-hill diffusion of hydrogen in Al. Inżynieria Mater. 2004, 25, 1-4. [CrossRef]

27. Łunarska, E.; Chernyayeva, O. Effects of hydrogen induced elastic and plastic straining on its transport in Al. Adv. Mater. Sci. 2007, 7, 153-159.

28. Ambat, R.; Dwarakadasa, E.S. Effect of hydrogen in aluminium and aluminium alloys: A review. Bull. Mater. Sci. 1996, 19, 103-114. [CrossRef]

29. Zieliński, A. Niszczenie Wodorowe Metali Nieżelaznych i Ich Stopów; Gdańskie Towarzystwo Naukowe: Gdańsk, Poland, 1999.

30. Włodarczyk, P.P.; Włodarczyk, B. Influence of hydrogen on shortening the operational reliability time of aluminum alloy construction. Instal 2013, 12, 32-34.

31. Moody, N.R.; Thompson, A.W.; Ricker, R.E.; Was, G.S.; Jones, R.H. (Eds.) Hydrogen effects on material behavior and corrosion deformation interactions. In Proceedings of the International Conference on Hydrogen Effects on Material Behavior and Corrosion Deformation Interactions, Moran, WY, USA, 22-26 September 2002.

32. Bockris, J.O.M.; Reddy, A.K.N. Modern Electrochemistry; Kulwer Academic/Plenum Publishers: New York, NY, USA, 2000; Volume 2B.

33. Tomaszow, N.D. Teoria Korozji i Ochrony Metali; Państwowe Wydawnictwo Naukowe: Warsaw, Poland, 1962.

34. Yasniy, P.V.; Okipnyi, I.B.; Maruschak, P.O.; Panin, S.V.; Konovalen, I.V. Crack tip strain localisation on mechanics of fracture of heat resistant steel after hydrogenation. Theor. Appl. Fract. Mech. 2013, 63-64, 63-68. [CrossRef]

35. Romaniv, O.N.; Nikiforchin, G.N. Mechanics of Corrosion Destruction of Structural Alloys; Metallurgy: Moscow, Russia, 1986. (In Russian)

36. Hoyos, J.J.; Masoumi, M.; Pereira, V.F.; Tschiptschin, A.P.; Paes, M.T.P.; Avila, J.A. Influence of hydrogen on the microstructure and fracture toughness of friction stir welded plates of API 5L X80 pipeline steel. Int. J. Hydrog. Energy 2019, 44, 23458-23471. [CrossRef]

37. Baszkiewicz, J.; Kamiński, M. Podstawy Korozji Materiatów; Oficyna Wydawnicza Politechniki Warszawskiej: Warsaw, Poland, 1997.

38. PN-EN 573-3:2019; Aluminum and Aluminum Alloys-Chemical Composition and Types of Forged Products-Part 3: Chemical Composition and Types of Wares. Polish Committee for Standardization: Warsaw, Poland, 2019.

39. PN-EN ISO 6892-1:2020-05; Metals-Tensile Test-Room Temperature Test Method. Polish Committee for Standardization: Warsaw, Poland, 2020.

40. PN-EN ISO 7539-6:2018-12; Corrosion of Metals and Alloys-Stress Corrosion Test. Preparation and Use of Specimens with Pre-Fracture for Testing under Constant Load or Constant Strain. Polish Committee for Standardization: Warsaw, Poland, 2018

41. PN-EN ISO 7539-1:2013-06; Corrosion of Metals and Alloys-Stress Corrosion Test-General Guidelines for Test Methods. Polish Committee for Standardization: Warsaw, Poland, 2013. 
42. PN-EN ISO 148-2:2017-02; Metals-Charpy Impact Test-Testing of Pendulum Hammers. Polish Committee for Standardization: Warsaw, Poland, 2017.

43. Jastrzębski, P.; Mutermilch., J.; Orłoś, W. Wytrzymałość Materiałów; Arkady: Warsaw, Poland, 1985.

44. Banasik, M. Ćwiczenia Laboratoryjne z Wytrzymałości Materiałów; Wydawnictwo Naukowe PWN: Warsaw, Poland, 1977.

45. Łączkowski, R. Wytrzymałość Materiałów; Wydawnictwo Politechniki Gdańskiej: Gdańsk, Poland, 1988.

46. Walczyk, Z. Wytrzymałość Materiałów; Wydawnictwo Politechniki Gdańskiej: Gdańsk, Poland, 1998.

47. Petrov, L.; Soproniuk, N. Corrosion-Mechanical Destruction of Metals and Alloys; Naukova Dumka: Kiev, Ukraine, 1991. (In Russian)

48. Petrov, L.; Olik, A.; Kalinkov, A. Electrochemical aspects of corrosion fatigue of an aluminum alloy of the Al-Zn-Mg system. Phys.-Chem. Mech. Mater. 1986, 5, 35-39. [CrossRef] 